\title{
Glenn Ole Hellekjær*
}

\section{A Survey of English Use and Needs in Norwegian Export Firms}

\begin{abstract}
The present needs analysis study uses data from a quantitative survey of language use and needs in 302 export firms to identify for which tasks and in which communicative situations English is used, and to what extent language difficulties are encountered. The survey data are then triangulated with those of two studies of job advertisements. The findings indicate that while a large number of staff in Norwegian export firms use English fairly well, many still experience difficulties involving language proficiency as well as communication skills. An important implication is that Norwegian institutions of higher education need to meet their students' need for advanced proficiency in General English, English for Specific Purposes as well as the communication skills needed in occupational contexts. The findings also indicate that the prevailing focus on communication skills in recent studies of Business English as a Lingua Franca is inadequate, and that such skills must be complemented with advanced English proficiency.
\end{abstract}

\section{Introduction}

Norwegians are reputedly quite proficient in English (Bonnet 2004, Education First 2012: 12). Despite this, a number of studies, several of which can be characterized as needs analyses (NAs), indicate that this proficiency may involve the mastery of everyday English, not the advanced proficiency required professionally in, for instance, academia (Hellekjær 2008, 2009, Lehmann 1999), business (Hagen et al. 2006, Hellekjær 2007, Lie/Skjoldmo, 1982) or governance (Hellekjær 2010). The present NA study focuses on English use and needs in business, more specifically, on Norwegian export firms.

\subsection{Needs Analyses}

In broad terms, a NA is an empirical analysis that aims to identify what "learners will be required to do with the foreign language in the target situation, and how learners might best master the target language during the period of training" (West 1994: 1). The idea of specially designed, focused language courses intended to meet specific needs is not an entirely new one (Howatt 1984). Before the 1970ies, however, NAs could be quite informal, and teaching was often based on "some kind of intutive or informal analysis of students' needs" (West 1994: 1). As often as not, these also focused on linguistic categories. This changed when Munby (1978) introduced a more systematic, performance-oriented approach that involved identifying language functions and situations for language use as a basis for instruction.

In the field of English for Specific Purposes (ESP), Hutchinson/Waters (1987) did the groundwork on needs analysis, distinguishing more systematically between target needs and learning needs. Dudley-Evans/St. John (1998: 125) go on to differentiate between a) target situation analysis and objective needs - identifying the tasks and activities English is to be used for, b) subjective and felt needs - the perceived needs that in turn may influence learning, and c) present situation analysis, which provide information about what the learners know and their current use of the target language. As part of the target situation analysis (see a) Dudley-Evans/St.

\footnotetext{
* Glenn Ole Hellekjar

University of Oslo

Department of Teacher Education and School Research

P.O. Box 1099 Blindern

N-0317 Oslo

g.o.hellekjar@ils.uio.no
} 
John (1998) include the professional communication aspect, that is to say knowledge of how language and skills are used in the target situation. This involves linguistic analysis, discourse analysis, and genre analysis.

More recently, there has been a movement towards task-based NAs using a mixed-methods approach (Teddlie/Tashakkori 2009) that utilizes multiple sources and methods to triangulate findings and provide better quality data (e.g. Jasso-Aguilar 2005, Long 2005). This is part of an increased focus on the validity of NAs in order to ensure that these are reliable decision-making tools (e.g. Dudley-Evans/St. John 1998, Long 2005). This brings us to the present needs analysis, in which I use data from a quantitative needs analysis survey of the English use and needs as perceived by 302 managers working in Norwegian export firms (Hellekjær 2007). The goal is to identify in which contexts and situations English is used in business, in which communication situations users experience difficulties, and for which areas and situations the respondents indicate the need for improved proficiency. These, to a large extent perceived needs, will be checked against two recent studies of Norwegian job advertisements (Doetjes/Vold, 2010, 2011). Finally, I will discuss some of the implications for Norwegian higher education.

\subsection{NAs in Europe and Norway}

The increasing use of English as an International Lingua Franca, not to mention the use of Business English as a Lingua Franca (BELF) has engendered a growing number of studies, many of which are NAs (Jenkins et al. 2011). The European studies seem unanimous about the central role of English in business, in which it is considered a must (Charles 2006, Ehrenreich 2010, Rogerson-Revell 2007), see also Hagen et al. (2006). However, while both English and the business user's first language (L1) are a must, proficiency in an additional language is considered an advantage (Ehrenreich 2010, Hagen, et al. 2006; Kankaanranta/Planken 2010).

Next, the studies agree on the use of BELF being highly contextualized - that is to say its use is "intertwined with... business communication competence, business competence and business know-how overall" (Kankaanranta/Louhiala-Salminen 2010: 207). On the one hand, this means "that language skills without the necessary professional profile are not sufficient" (Ehrenreich 2010: 417). On the other, it means that business knowledge can, to some extent at least, compensate for poor language skills and help repair or improve communication.

Furthermore, BELF respondents are fairly pragmatic users of English, focusing more on clarity and successful communication than on grammatical correctness or fine nuances of meaning. Despite this, many non-native speakers (NNS) experience language and communication difficulties, ranging from finding the words they need to being able to interrupt, ask for clarification, or spontaneously present or argue for one's views (Charles 2006, Ehrenreich 2010, Rogerson-Revel, 2007, Taillefer 2007). Another sign of language difficulties is that many NNS experience difficulties with native speakers (NS). This can be because of the latter's speaking speed, fluency or advanced and nuanced vocabulary, or because "native speakers frequently use their native competence as an instrument of power" (Ehrenreich 2010: 422); see also (Rogerson-Revell 2010). Indeed, how well, or how poorly native speakers accommodate to non-native speakers is a recurring issue (e.g. Rogerson-Revell 2010, Sweeney/Hua 2010). In other words, the importance of advanced English proficiency in BELF contexts is a point of contention. In their review article, Jenkins et al. (2011: 299) argue that:

BELF studies demonstrate that intercultural communication skills rather than NS English correctness are key... [and] that communication and accommodation, rather than mastery of NS English forms, should be the focus of business English instruction.

I would argue that much of the data in the articles reviewed by Jenkins, as well as other studies, merit a different interpretation. This is that good communication skills must be complemented by advanced levels of English proficiency, in General English as well as English for Specific Purposes (ESP). Indeed, Taillefer's (2007) NA gives a French perspective on how problematic 
inadequate English skills may be. Before returning to this issue, however, I will briefly present some Norwegian NAs.

The Norwegian NAs that have been carried out so far have almost exclusively been quantitative surveys of language use and needs in business. They have largely focused on which languages are used, in which situations and for which tasks, and on language problems the users may have experienced or can identify (Hagen et al., 2006, Norges Handelshøyskole 1973, Hellekjær 1991, 2007, Hellum/Dypedahl 1998, Lie/Skjoldmo 1982). Three have used a different approach (Doetjes/Thue-Vold 2010, 2011, Kvam/Schewe 1984), examining job advertisements with regard to whether, and how, employers specify language skills when advertising for new employees. Finally, Gundersen (2009) carried out a qualitative study that revealed a clear lack of language management policies in a number of Norwegian subsidiaries in Belgium (see also Hagen et al. 2006). To sum up, the Norwegian findings largely reflect those in the European studies mentioned above, that English is the dominant language in business, and that there is a lack of staff with advanced proficiency in English because these, as often as not, are forced to rely on their foreign language skills from upper-secondary school. These are, by all parties involved considered "utterly inadequate in all languages" (my translation, Lie/Skjoldmo 1982: 28, see e.g. Hagen et al. 2006).

This brings us to the present study, for which I as mentioned use data from a national, quantitative needs analysis involving 302 managers in Norwegian export firms (Hellekjær 2007) to examine this issue in further detail.

\section{Method, questionnaire, procedure, sample and validity}

The present quantitative study uses a quasi-experimental, one-group, post-test research design (Shadish/Cook/Campbell 2002: 106-107). The statistical analysis, which uses the Statistical Processing Program for the Social Sciences (SPSS), is largely descriptive and concentrates on frequency analyses.

The questionnaire was developed by myself, staff at Østfold University College (www.hiof. $\underline{\text { no)}}$ ), at the Norwegian Centre for Foreign Languages in Education (www.fremmedspraksenteret. no/), and VOX, the Norwegian National Centre for Education in Business (www.vox.no). It comprised a wide range of items ranging from background variables such as the firms' size in terms of number of employees, location, branch, and about whether they were involved in exporting and importing and in which markets. Since previous surveys indicated that English is often used even when other languages, such as German or Spanish, would have been preferable, a number of items were included to crosscheck this. Furthermore, there were items about the firms' working language, about the tasks for which foreign languages are used, about problems encountered due to inadequate language proficiency, the need for in-service language courses, the respondents' views about the future need for foreign languages, and finally, about taking language proficiency into consideration when hiring staff. The questionnaire, in Norwegian, can be found in Hellekjær (2007- http://www.hiof.no/neted/upload/attachment/site/group55/Fokusnr3.pdf).

The survey was carried out by the market research provider Field-Work Scandinavia (http:// www.fieldwork.no/). They used an e-base with 40,000 respondents aged 15 years and older, selected at random and recruited by telephone. At the time of the survey, December 2005, the e-base included 7844 executives, of which 1852 were CEOs. Of these, 1600, selected at random, were contacted by e-mail. They comprised executives from export and import firms as well as those catering to the domestic market only. Of these, 1032 returned filled-in questionnaires, amounting to a $64 \%$ reply rate. Table 1 provides an overview of the sample, first for the sample as a whole, and separately for the firms involved in exports and imports. There may be some overlap between the importer and exporter categories. 


\begin{tabular}{lccc}
\hline Trade & $\begin{array}{c}\text { All firms } \\
N=1032\end{array}$ & $\begin{array}{c}\text { Export firms } \\
\text { subsample } \\
n=302\end{array}$ & $\begin{array}{c}\text { Import firms } \\
\text { subsample } \\
n=362\end{array}$ \\
\hline Mining, agriculture, forestry, & 1 & 1 & 0 \\
fisheries & & & \\
Manufacturing & 15 & 32 & 25 \\
Power utilities & 1 & 0 & 1 \\
Construction & 9 & 3 & 8 \\
Commodity trade & 18 & 14 & 32 \\
Hotels and restaurants & 2 & 2 & 1 \\
Transport and communications & 7 & 6 & 6 \\
Financial services & 5 & 1 & 2 \\
Real estate, sales and rentals & 2 & 8 & 5 \\
Computer services & 5 & 31 & 18 \\
Other services & 35 & 100 & 100 \\
Total & 100 & & \\
\hline
\end{tabular}

Table 1. An overview of the sample according to trade, with subsamples comprising the firms involved in exporting and importing, in percent. $N=1032$

The following analysis focuses on the 302 export firms. It should be mentioned that the analysis in Hellekjær (2007) showed that the data from the 362 import firms closely mirror those from the export firms. I would argue that this sample is sufficient to provide a useful picture of language use and needs in Norwegian exporting. However, there is one limitation affecting validity that should be kept in mind. This is due to the respondents being primarily mid or top-level managers, who may or may not have a complete and detailed overview of export activities in their firm. Reeves/ Wright (1998: 38) put this as follows:

\footnotetext{
... mismatches between perceptions of foreign language use held by different layers of management were found to occur. Senior and middle management sometimes had differing or even erroneous ideas of foreign language use when it came to everyday realities dealt with by individuals
}

It is therefore probable that a follow-up survey and/or interviews of staff in other positions who are actually involved in exporting activities, such as secretaries, telephone operators or sales personnel, would provide richer and more accurate information. Nevertheless, even though the respondents might not have a detailed overview of all export activities involving language use, their answers should still provide useful and valid information on management perceptions about the use of, and need for English language proficiency in Norwegian export firms.

\section{Results and analysis}

The following section starts by presenting additional detail about the sample. It continues with an overview of export markets compared to languages used, of communicative situations and the difficulties encountered, and finally, about the perceived need for improved language skills.

\subsection{Background of the sample}

Compared to the overall sample of 1032 firms, the 302 exporters have a markedly larger percentage of manufacturing firms ( $32 \%$ compared to $15 \%$ overall), and a larger proportion of firms with more than 400 employees ( $21 \%$ compared to $12 \%$ ) in the sample as a whole. In addition, it has a larger proportion of firms that use English as a working language, 17\% compared to $8 \%$ in the sample as a whole. The number of firms with more than 100 employees is also much higher among the firms using English as a working language. With regard to their level of education, of the 302 respondents, $67 \%$ (204) had a university level education, 26\% (80) upper secondary school, and 6\% (18) lower secondary school only. 


\subsection{Export markets and languages used}

A key item in this survey was which areas the firms exported to. The answers are displayed in Table 2 .

\begin{tabular}{lcc}
\hline Export markets & Answers & Answers in percent \\
\hline Other Nordic countries & 219 & 72 \\
European countries & 240 & 79 \\
USA/Canada/Australia & 141 & 47 \\
Asia & 111 & 37 \\
Africa & 64 & 21 \\
Latin America & 56 & 18 \\
Cannot answer & 6 & 2 \\
\hline
\end{tabular}

Table 2. Export markets, ranked according to importance. $N=302$

Not unexpectedly, the data shows that other Nordic countries and European countries are among Norway's main export markets. They are followed by about $47 \%$ of the firms export to Englishspeaking countries such as USA, Canada and Australia. Great Britain, an important market, is subsumed in the category European countries. However, an item on languages that used openended questions, in which respondents filled in the foreign languages used according to importance, provides additional data that enables a closer examination.

\begin{tabular}{lcc}
\hline Languages & Answers & Answers in percent \\
\hline English & 286 & 95 \\
German & 52 & 17 \\
Norwegian/Swedish/Danish & 50 & 16 \\
French & 23 & 8 \\
Spanish & 12 & 4 \\
Russian & 8 & 3 \\
Other languages & 20 & 7 \\
\hline
\end{tabular}

Table 3. Languages used for exporting, ranked according to importance. $N=302$

As can be seen, English is used for almost $95 \%$ of the export activities, far in excess of the English speaking countries' market share. It is used even when using other languages such as German, French or Spanish would have been more logical. A comparison with the 1973 figures (Norges Handelhøyskole 1973), where 81\% used English, 48\% German, 21\% French, and 3\% Spanish, also shows that the use of German and French has decreased dramatically over the last 30 years. Language choice notwithstanding, the next question is whether Norwegian exporters have staff with high enough levels of English proficiency, from the ability to carry out everyday oral conversation and writing e-mails to mastering sales and negotiations in demanding communication situations.

\subsection{Communicative situations}

Table 4 presents answers to the question about how the respondents communicate with firms abroad, and how frequently these means of communication are used. There were a high number of missing answers, with only 151 of the 302 respondents from export firms answering. The missing answers might be due to difficulties involved in answering on behalf of other staff members. 


\begin{tabular}{lccccc}
\hline Means of communication & 5 & 4 & 3 & 2 & $\begin{array}{c}1 \\
\text { Frequently }\end{array}$ \\
& $88 \%$ & $8 \%$ & $2 \%$ & $2 \%$ & \\
\hline E-mail & $50 \%$ & $30 \%$ & $15 \%$ & $5 \%$ & \\
Telephone & $9 \%$ & $15 \%$ & $50 \%$ & $24 \%$ & $1 \%$ \\
Personal contact & & & & & \\
(face to face) & $11 \%$ & $16 \%$ & $24 \%$ & $42 \%$ & $7 \%$ \\
Telefax & $4 \%$ & $11 \%$ & $20 \%$ & $52 \%$ & $13 \%$ \\
Letter & $7 \%$ & $10 \%$ & $13 \%$ & $36 \%$ & $34 \%$ \\
External agents & & & & & \\
\hline
\end{tabular}

Table 4. How does your staff communicate with firms abroad? The answers are in percent. $N=151$

The answers show that e-mail and telephone are by far the most frequent means of communication used. Personal contacts are also fairly frequent. Another item asked about the importance of good English skills in a number of situations, and the distribution of answers gives an impression of where these are most needed.

\begin{tabular}{|c|c|c|c|c|c|}
\hline Tasks/activities & $\begin{array}{c}5 \\
\text { Very } \\
\text { necessary }\end{array}$ & 4 & 3 & 2 & $\begin{array}{c}1 \\
\text { Not necessary }\end{array}$ \\
\hline Negotiating/writing contracts & $75 \%$ & $9 \%$ & $7 \%$ & $3 \%$ & $6 \%$ \\
\hline Marketing/sales/services & $61 \%$ & $19 \%$ & $11 \%$ & $4 \%$ & $6 \%$ \\
\hline Secretarial tasks & $38 \%$ & $28 \%$ & $19 \%$ & $7 \%$ & $9 \%$ \\
\hline Budgets/accounting & $18 \%$ & $21 \%$ & $21 \%$ & $18 \%$ & $21 \%$ \\
\hline Research/development & $39 \%$ & $22 \%$ & $13 \%$ & $7 \%$ & $16 \%$ \\
\hline Production & $24 \%$ & $18 \%$ & $22 \%$ & $15 \%$ & $19 \%$ \\
\hline Conferences/seminars & $41 \%$ & $29 \%$ & $18 \%$ & $5 \%$ & $7 \%$ \\
\hline $\begin{array}{l}\text { Giving talks/making } \\
\text { presentations }\end{array}$ & $47 \%$ & $24 \%$ & $13 \%$ & $7 \%$ & $9 \%$ \\
\hline Contacting customers/sales & $51 \%$ & $21 \%$ & $14 \%$ & $6 \%$ & $8 \%$ \\
\hline
\end{tabular}

Table 5. How necessary is it that the staff involved in the following tasks, are able to communicate in English? $N=302$

The most important situations in which the respondents feel that good English is important are, in order of designated importance: negotiations/contract writing, sales and marketing, contacting customers, giving talks/making presentations and conferences and seminars. At the same time, they indicate that these are situations that require a lot from the users with regard to proficiency. This can be compared with the answers to the questions about the language difficulties the respondents were aware of.

\subsection{Language difficulties}

One of the key questions in the survey was "Have your firm or staff experienced difficulties due to poor English/foreign language proficiency in any of the following areas?" The respondents could answer yes, no, or do not know, and the main areas of possible difficulty were:

- Failed sales or contract negotiations

- Delivery problems

- Insulting a customer or business partner

- Being unable to follow up a business network or business partners

- Being unable to take part in dinner conversations or other social events

- Avoiding export markets or customers 
It should be mentioned that answers to the do-not-know category might have room for several interpretations. One may be that the respondents are uncertain or unaware of whether colleagues or subordinates have experienced communication breakdowns (see Reeves/Wright 1998). Another is that possible difficulties, such as failed negotiations, might also be due to cultural difficulties or poor communication skills, not necessarily poor English. Third, the difficulties may be due to the buyer's poor language or communication skills, as some respondents indicate in VerstraeteHansen's (2008) NA from Danish business. A final point is that it is often impossible to determine exactly why a deal falls through or negotiations fail. I would therefore argue that the do-not-know answers can provide useful information about the extent of what can be termed "undetermined variance". These answers should therefore, with great caution, be taken into consideration when interpreting the distribution of answers displayed in Figure 1.

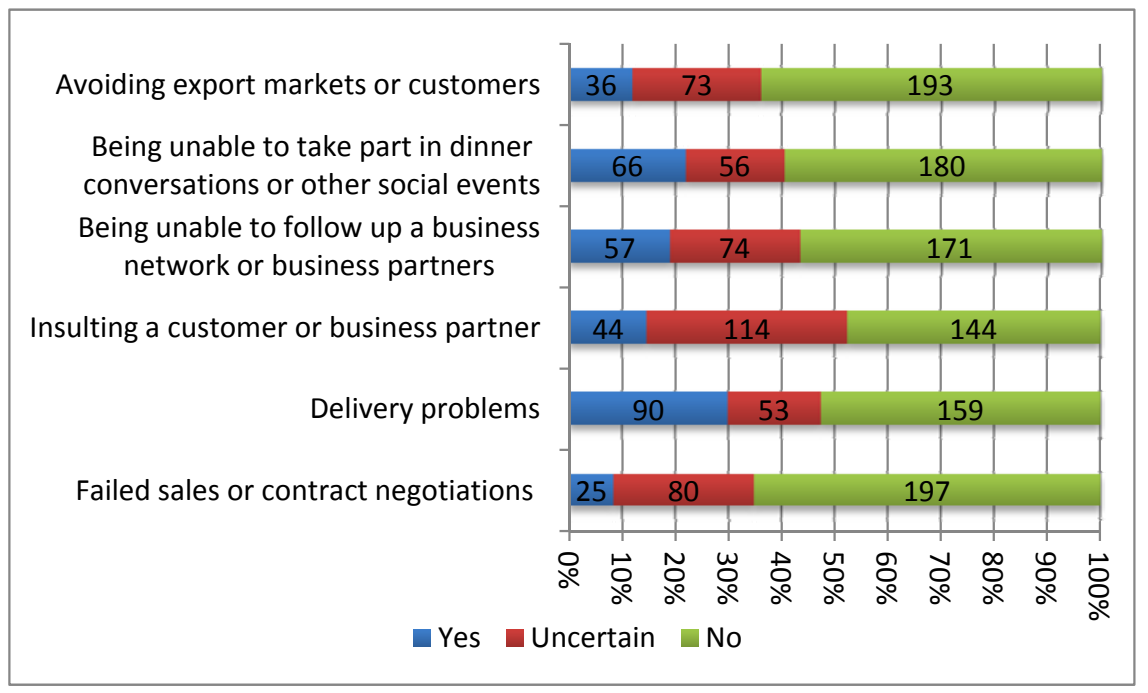

Figure 1. Export difficulties due to English language problems. $N=302$

The answers displayed in Figure 1 have two interpretations. One is that the majority of respondents do not experience mentionable communication problems in English - indeed, many seem to manage fairly well. The other interpretation is that while a fairly low percentage of respondents have experienced communication difficulties that can be attributed to poor English, the larger number of do-not-know answers indicate great uncertainty. When 122 (40\%) out of 302 presumptively well-educated respondents find it difficult to converse in English during social events, or feel uncertain about their ability to do so, poor General English proficiency is probably an important reason. The same is the case for the apparent difficulties with regard to following up business networks or partners. Next, difficulties with business-related communication in English is a possible interpretation when as many as $158(55 \%)$ of the respondents admitted to inadvertently having insulted, or to being uncertain about having insulted, a customer or fellow businessman. The same is the case when $143(47 \%)$ have, or suspect that they have experienced delivery problems due to language difficulties.

As already mentioned, it is probable that some of these communication difficulties are either caused, or compounded by, cultural issues (see Hellum/Dypedahl 1998, Hagen et al. 2006). Indeed, this is confirmed by answers to a question in the survey asking to what extent the firms found it necessary to improve their staff's knowledge of social and cultural issues. The answers are displayed in Table 6. 


\begin{tabular}{lccccc}
\hline & 5 & 4 & 3 & 2 & 1 \\
Strongly agree & & $\begin{array}{c}\text { Neither agree } \\
\text { nor disagree }\end{array}$ & & $\begin{array}{c}\text { Strongly } \\
\text { disagree }\end{array}$ \\
\hline Export firms & $45(15 \%)$ & $108(36 \%)$ & $99(33 \%)$ & $31(10 \%)$ & $19(6 \%)$ \\
\hline
\end{tabular}

Table 6. It is important that staff learn more about other countries' societies and cultures. $N=302$

That more than $50 \%$ of the exporters to varying degrees agree with this statement goes to show that they are aware of this issue. It is, however, interesting to note that as many as $49 \%$ are either neutral or disagree. This contrasts with the findings in the ELAN survey (Hagen et al. 2006), which showed that Norwegians and Swedes seem to have greater difficulties in this area than did their counterparts in other European countries.

\subsection{Course needs}

The items on the need for language courses are intended to identify whether the firms feel the need for improved proficiency at all, and in which languages.

\begin{tabular}{lcc}
\hline $\begin{array}{l}\text { Does your firm need improved skills in any of } \\
\text { these languages? }\end{array}$ & Number of answers & Answers in percent \\
\hline English & & \\
German & 150 & 50 \\
French & 105 & 35 \\
Spanish & 76 & 25 \\
Russian & 68 & 22 \\
Chinese & 44 & 15 \\
\hline
\end{tabular}

Table 7. The export firms' perceived need for improved language skills. Several answers are possible. $N$ $=302$

The main implication from these answers is that many firms need improved language proficiency in English as well as in other foreign languages, and the high number of answers for English most probably indicates an awareness of quality problems. Two other items provide additional information about what positive effects the firms feel improving language skills in English and other foreign languages could entail, as can be seen in Table 8 .

\begin{tabular}{lcc}
\hline $\begin{array}{l}\text { Positive consequences of improved skills in English } \\
\text { and other foreign languages }\end{array}$ & English & Other foreign languages \\
& \\
\hline Improved information flow/gathering & $124(41 \%)$ & $129(43 \%)$ \\
A larger network & $114(38 \%)$ & $149(49 \%)$ \\
More foreign customers & $48(16 \%)$ & $84(28 \%)$ \\
Increased turnover & $45(15 \%)$ & $67(22 \%)$ \\
Improved staff mobility & $63(21 \%)$ & $59(19 \%)$ \\
Other & $6(2 \%)$ & 4 \\
\hline
\end{tabular}

Table 8. Would improving your staff's skills in English/other foreign languages have any of the following consequences? Several answers are possible. $N=302$

The answers to these questions show that the respondents find that there is much to gain from improved proficiency in English and to an even greater extent, in other foreign languages. It is interesting to note that it is not necessarily additional customers or increased turnover they consider the main advantage, at least not in the first instance. Instead, the majority feels that the main 
advantage would be improved ability to develop and maintain business networks and improved information gathering capacity. A possible explanation for the lower numbers for customers and turnover could be that firms devote their most proficient staff to sales and sales-related activities, but that these resources are limited. In comparison, networking and information gathering involve larger numbers of staff in a variety of formal and informal settings, which means that much could be gained through improved proficiency.

\subsection{Language needs in job advertisements}

As mentioned by Long (2005), a mixed-methods approach makes it possible to triangulate survey findings with other data. This was, unfortunately, not part of the original exploratory study (Hellekjær 2007), and this was left to follow-up studies, three of which have been carried out. Two of these are by Doetjes/Thue-Vold $(2010,2011)$. In these, the authors sampled the number of online job advertisements mentioning foreign languages in Norway's largest online marketplace, www. finn.no, and vacancies in the Norwegian Labour and Welfare Administration's job database www.

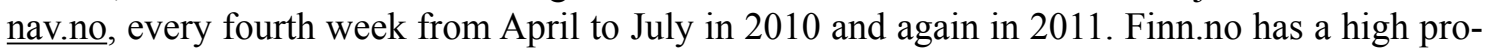
portion of advertisements from the private sector, nav.no more from the public sector, and the amount of vacancies vary from 7000 to 10000 vacant jobs each month. How, and how often employers signal the need for good English skills, can be seen as recognition of the importance of advanced English proficiency.

In the first 2010 study, about $20 \%$ of the jobs on finn.no mention English, compared to about $6 \%$ on nav.no, while in 2011 the percentages had increased to $25 \%$ and $7 \%$ respectively. For other languages than English the percentages vary from $1 \%$ to $2 \%$. The majority of advertisements also mentioned English as an explicit requirement, and almost always in combination with a professional degree, most frequently involving positions in engineering, sales, computing and business administration. In comparison, other foreign languages could be sought after, but were rarely required.

Despite the considerable number of advertisements requiring English skills, Doetjes/ThueVold $(2010,2011)$ observed that many employers frequently failed to mention English skills in advertisements for positions where this would have been highly relevant. They suggest that this might be because many employers take English skills for granted when hiring, and only specify these as requirements when particularly advanced proficiency is needed.

To return to the advertisements in which English skills are explicitly required, I would argue that this is a clear sign of businesses feeling the need for advanced English proficiency. This is because, as analyzed by Grin/Sfreddo/Vaillancourt (2010), introducing additional requirements such as language when hiring such professionals in engineering, sales, computing and business administration increases hiring costs and makes it more difficult to fill positions. In other words, when many employers specifically require English skills when advertising a position, this is a clear indication that they need such skills. I would therefore argue that this supports the interpretation of the survey data that many firms do have difficulties with inadequate English proficiency among their staff.

\section{Discussion}

A key aim of this study was to identify contexts and situations in which English is used in business communication situations in which users experience difficulties, and the areas and situations in which the respondents indicate the need for improved proficiency.

The first finding in the present study is the overwhelming importance of English in Norwegian exporting. Not only is it often a working language in the firm, it is also used for $95 \%$ of the export activities, in English as well as in non-English speaking areas. Next, although the most frequent means of communication in English are e-mail and telephone, face-to-face meetings are quite frequent. It is in many of these face-to-face meetings, those that involve linguistically demanding 
tasks such as negotiations, sales and marketing, making presentations, and contacting customers, that language problems appear. On the one hand, as can be seen in Figure 1, it would seem that the majority manage quite well, as is also claimed in BELF studies. On the other, the concrete examples of communication failure, also evident in BELF studies, along with the considerable uncertainty about the reasons behind failed sales and negotiations, are evidence of inadequate English as well as of communication difficulties. It could be mentioned that the findings were almost identical for all the 362 import firms included in the survey.

This conclusion is further supported by many firms indicating that they needed courses to improve English skills, and by the answers to the question about whether and how the firms stood to gain from this. These ranged from improved turnover to greater staff mobility, and even more important for many, improved network building and information gathering capacity. The need for staff with advanced English is further confirmed by the findings of two separate studies of job advertisements making this an explicit requirement for engineering, sales, computing and business administration staff in particular (Doetjes/Thue-Vold 2010, 2011).

\subsection{Validity}

Before continuing with these implications, it might be useful to return briefly to the issue of validity. The main point to keep in mind is that the findings of the present study to a large extent reflect those in other Norwegian studies of language use in business, past and present (Gundersen 2009, Hagen et al. 2006, Hellekjær 1991, Hellum/Dypedahl 1998, Kvam/Schewe 1984, Lie/ Skjoldmo 1982). This is also the case with a recent, comparable Danish study, Hvad skal vi med sprog? (Do we really need languages?) (Verstraete-Hansen 2008). Indeed, Verstraete-Hansen's (2008) study reveals even greater problems in Demark than those found in Norway. Furthermore, the findings also reflect those of recent BELF studies (Charles 2006, Ehrenreich 2010, Jenkins et al. 2011, Kankaanranta/Louhiala-Salminen 2010, Kankaanranta/Planken 2010, Lehtonen/Karjalainen 2008, Louhiala-Salminen/Charles/Kankaanranta 2005, Nickerson 2005, Rogerson-Revell 2007, 2010, Sweeney/Hua 2010). Indeed, given Norwegians' reputation for being proficient in English (Bonnet 2004, Education First 2011: 12), the data in the present study go far in countering Jenkins et al.'s (2011) claim that communication skills may be more important than language proficiency in BELF. This is also indicated, albeit more indirectly, by Doetjes/Thue-Vold's (2010, 2011) job advertisement NAs.

Of course, the validity of the present study could have been improved through a mixed-methods approach, as argued by Long (2005). It would have been particularly useful to interview or survey a number of staff in different positions in a limited number of firms. Not only would this have provided richer information on needs and difficulties, it would also have helped check on the accuracy of many of the answers from the manager respondents in the present study.

Nevertheless, I would argue that the findings of the present study give a useful insight into managers' views of English use and needs in Norwegian export firms, and that these should have serious implications for the Norwegian institutions of higher education that educate the staff who work in international contexts.

\subsection{Implications for higher education}

The main implication for institutions of higher education is accepting that many, or most of their students need to be prepared to use English professionally, in linguistically and inter-culturally demanding situations and contexts, and in many cases as a working language. It also means keeping in mind that English proficiency is an important competitive advantage when seeking employment. In fact, Grin et al. (2010) have found that European professionals with high levels of English proficiency, more often than not, command higher-than-average wages.

This means colleges and universities need to work to improve the students' general English proficiency on the one hand, and on the other, ESP and communication skills, ranging from do- 
main-specific vocabulary and oral and written genres to the knowledge of and training in handling meetings, negotiations, sales and presentations. Improving the students' intercultural awareness comes in addition. This will probably need to be done through a combination of separate language and communication courses, by encouraging stays abroad, as well as through the integration of language learning goals into English-Medium courses - which are non-language courses taught through English. This would require fairly comprehensive support of English specialists and entail close collaboration between content and language specialists with regard to teaching, examinations and assessment (see Wilkinson et al. 2006). Above all, it means that institutions of higher education outside of the English-speaking areas, in Norway and elsewhere, need a clear language policy with regard to ensuring that their students develop the English proficiency they will need.

\section{Conclusion}

The present study of business use of and need for English clearly shows that educated professionals need improved English proficiency to function in an increasingly international workplace. It would of course be useful with follow-up studies, first and foremost qualitative, that could provide additional, rich information about how professionals use English in occupational situations. It would also be useful with additional surveys of how institutions of higher education teach, or do not teach, the English their students will need. However, I would argue that in Norway the situation has been documented well enough, and that it is action that is currently needed.

In Norway this means, as mentioned above, that institutions of higher education need to recognize that upper-secondary level English instruction is not enough, and accept their responsibility to prepare their students for future careers in which they will need advanced English proficiency. In other words, they urgently need to revise their course goals and study plans to better prepare their students for the multilingual present and future.

\section{References}

Bonnet, Gerard (ed.). 2004: The assessment of pupils'skills in English in eight European countries 2002. The European network of policy makers for the evaluation of educational systems.

Charles, Mirjaliisa 2006: Language matters in global communication. In Journal of Business Communication, 44(3), 260-282.

Doetjes, Gerard/Thue-Vold, Eva 2011: Engelsk og andre fremmedspråk fortsatt sjeldent nevnt i stillingsutlysninger. Halden: Fremmedspråksenteret.

Doetjes, Gerard/Thue-Vold, Eva 2010: Engelsk og andre fremmedspråk sjeldent nevnt i stillingsutlysninger. Halden: Fremmedspråksenteret.

Dudley-Evans, Tony/St. John, Maggie Jo 1998: Developments in ESP: a multi-disciplinary approach. Cambridge: Cambridge University Press.

Education First 2011: EF English Proficiency Index [online]. http://www.ef.no/epi/download-full-report/ (accessed 9 October 2011).

Ehrenreich, Susanne 2010: English as a business lingua franca in a German multinational corporation. Journal of Business Communication, 47(4), 408-431.

Grin, François/Sfreddo, Claudio/Vaillancourt, François 2010: The economics of the multilingual workplace. New York: Routledge.

Gundersen, Sigrid L. 2009: Language management: in multinational companies. Bergen: SNF.

Hagen, Stephen/Davila-Philippon, Santiago/Nordgren, Bjorn 2006: ELAN: Effects on the European Economy of Shortages of Foreign Language Skills in Enterprise. London: The UK National Centre for Languages (CiLT).

Hellekjær, Glenn O. 2010: Språkmakt og avmakt: bruk av og behov for fremmedspråk i statsforvaltningen. Halden: Fremmedspråksenteret.

Hellekjær, Glenn O. 2009: Academic English reading proficiency at the university level: A Norwegian case study. Reading in a Foreign Language, 21(2), 198-222.

Hellekjær, Glenn O. 2008: A Case for Improved Reading Instruction for Academic English Reading Proficiency. Acta Didactica Norge, 2(1), 1-17. 
Hellekjær, Glenn O. 2007: Fremmedspråk i norsk nceringsliv - engelsk er ikke nok! (Vol. 3). Halden: Fremmedspråksenteret.

Hellekjær, Glenn O. 1991: The Use of and Need for Foreign Language Skills in 24 Norwegian Export Firms: A Survey. Språk og Språkundervisning(1), 21 - 44.

Hellum, Bjørg/Dypedahl, Magne 1998: Business Communication and Cultural Awareness in Norwegian Companies. Halden: Østfold University College.

Howatt, Anthony P. R. (1984): A history of English language teaching. Oxford: Oxford University Press.

Hutchinson, Tom/Waters, Alan 1987: English for Specifc Purposes: a learning centred approach. Cambridge: Cambridge University Press.

Jasso-Aguilar, Rebecca 2005: Sources, methods and triangulation in needs analysis: A critical perspective in a case study of Waikiki hotel mails. In Michael H. Long (ed.), Second Language Needs Analysis. Cambridge: Cambridge University Press, 127-168

Jenkins, Jennifer/Cogo, Alessia/Dewey, Martin 2011: Review of developments in research into English as a lingua franca. Language Teaching, 44(3), 281-315.

Kankaanranta, Anne/Louhiala-Salminen, Leena 2010: “English? - Oh, it's just work!”: A study of BELF users' perceptions. [Reseach and Discussion Note]. English for Specific Purposes, 29, 204-209.

Kankaanranta, Anne/Planken, Brigitte 2010: BELF competence as business knowledge of internationally operating business professionals. Journal of Business Communication, 47(4), 380-407.

Kvam, Sigmund/Schewe, Theo 1984: Tyskkunnskaper i Norsk Nceringsliv: En Analyse av Behov og Etterspørsel. Halden: Østfold Distriktshøgskole.

Lehmann, Torunn M. 1999: Literacy and the Tertiary Student: Why has the Communicative Approach Failed? Dr. Philos., University of Bergen, Bergen.

Lehtonen, Tuula/Karjalainen, Sinikka 2008: University graduates' workplace needs as percieved by employers. System, $36,492-503$.

Lie, Ulf/Skjoldmo, Sissel 1982: Behovet for fremmedspråkkompetanse i nceringslivet. Bergen: Universitet i Bergen/ Hordaland Lektorlag.

Long, Michael H. 2005: Second language needs analysis. Cambridge, UK; New York: Cambridge University Press.

Louhiala-Salminen, Leena/ Charles, Mirjaliisa/Kankaanranta, Anne. 2005: English as a lingua franca in Nordic corporate mergers: Two case companies. English for Specific Purposes, 25, 401-421.

Munby, John 1978: Communicative syllabus design: a sociolinguistic model for defining the content of purpose-specific language programmes. Cambridge: Cambridge University Press.

Nickerson, Catherine 2005: English as a lingua franca in international business contexts. [Editorial]. English for Specific Purposes, 24, 367-380.

Norges Handelshøyskole 1973: Siviløkonomers bruk av fremmedspråk. Bergen: Norges Handelshøyskole.

Reeves, Nigen/Wright, Colin 1998: Linguistic Auditing. Clevedon: Multilingual Matters.

Rogerson-Revell, Pamela 2010: Can you spell that for us nonnative speakers? Journal of Business Communication, 47(4), 432-454.

Rogerson-Revell, Pamela 2007: Using English for International Business: A European case study. English for Specific Purposes, 26, 103-120.

Shadish, William R./Cook, Thomas D./Campbell, Donald T. 2002: Experimental and Quasi-Experimental Designs for Generalized Causal Inference. Boston: Houghton Mifflin.

Sweeney, Emma/Hua, Zhu 2010: Accommodating towards your audience. Journal of Business Communication, 47(4), 477-504.

Taillefer, Gail F. 2007: The professional language needs of Economics graduates: Assessment and perspectives in the French context. English for Specific Purposes, 26, 135-155.

Teddlie, Charles/Tashakkori, Abbas. 2009: Foundations of mixed methods research: integrating quantitative and qualitative approaches in the social and behavioral sciences. Los Angeles: SAGE.

Verstraete-Hansen, Lisbeth 2008: Hvad skal vi med sprog? Copenhagen: Copenhagen Business School.

West, Richard F. 1994: Needs analysis in language teaching. Language Teaching, 1-19.

Wilkinson, Robert/Zegers, Vera/van Leeuwen, Charles. 2006: Bridging the assessment gap in English-medium higher education. Bochum: AKS-Verlag. 